\title{
Effectiveness Analysis of Working Capital on MSME Handycraft
}

Laras Nada Wahyu Atika' ${ }^{1}$, Agus Sukoco, ST., MM²

Narotama University

wahyunada97@gmail.com

\begin{abstract}
This study aims to determine the effectiveness of working capital management in MSME Rozatajaya Souvenir in Sidoarjo through the analysis of liquidity and activity ratios. The research method is using descriptive qualitative. Data obtained from financial transaction records for two semesters of 2018. The results of this study found that the average Liquidity Ratio was very good which included Current Ratio of 3.02, Quick Ratio of 2.93 and Cash Ratio of 2.25. The effectiveness of working capital using the Activity Ratio was considered less effective including the average Working Capital Turnover of 1.23, Receivable Turnover of 4.22 and Turnover Inventory of 14.95 times. The findings of this study, working capital is very necessary for business operations, however, management of working capital is still not effective so it requires a strategy to increase the effectiveness of working capital in business development.

Keywords: Working Capital, Liquidity Ratio, Activity Ratio.
\end{abstract}

\section{INTRODUCTION}

In running a business, of course business people need working capital, to finance their daily operations. Where the funds that have been used are expected to be able to re-enter the company, in the short term through the results of the sale of the product. So financial managers must be selective in their sources and use of working capital so that the company's operations are always fulfilled.

Working capital is a company's investment in short-term assets such as cash, securities (securities), trade receivables and inventories [1]. In this opinion, it can also be interpreted that working capital is the overall current assets of the company allocated in the operational activities of the company.

Working capital is a very important component in a company's activities. Working capital consists of four main components, namely cash, securities, inventories and accounts receivable where the component will guarantee the liquidity and sustainability of the company. With sufficient working capital, the company will be allocated. But if the working capital is large or excessive shows that there are unproductive funds, and can reduce profitability. Conversely, if the working capital is little or less can interfere with the production process, which can reduce company profits. So the availability of sufficient working capital is very important for the company, enough in the sense of not lacking and not short of funds, existing working capital in accordance with the company's capacity, so as to facilitate the company's operational activities as efficiently as possible and can reduce the risks that may occur. So there is accuracy in the determination and management of funds to determine the amount and quality of working capital used so that company activities are more efficient.

The effectiveness of working capital is the success rate of a company in using working capital in accordance with the stipulated provisions, so it does not conclude the advantages or disadvantages and can provide a satisfying ratio [2]. So that if the company is able to optimize and use working capital efficiently, the company can increase its profitability. Then it needs to be well regulated for the smooth operation of the company which will result in the continuity of the company.

The same as MSME Rozatajaya Souvenir in Sidoarjo in managing its working capital, which is required to always maintain the amount of working capital that benefits the company so that it can operate smoothly. This can show that good working capital management will affect the overall sustainability of the MSME. but financial reports that have not been properly managed have made it difficult for details of working capital.

Based on the description above, the purpose of this study was to determine the management of working capital in the MSME Rozatajaya Souvenir in Sidoarjo. To analyze the level of effectiveness of working capital management at MSME Rozatajaya Souvenir in Sidoarjo.

In the case, the results of various previous studies in the from of findings and theories can be used as a basis or reference and supporting data that are relevant to the problems related to this research. 
From previous research by Sukoco, N.P \& ZA with the title Management of Micro Business Working Capital to Obtain Profitability at UD. Warna Jaya Period 2011-2013. The results of the research function of Production or Operations are managed quite well, especially in terms of working capital management to increase profitability [3].

Research by Wahyuni with the title Efficient Analysis of Working Capital Usage at UD. Jombang Arifa Souvenir the results of the study show that liquidity has increased, the activity level of each ratio has decreased, while the profitability ratio has decreased [4].

The study by Goso \& Indriani with the title Analysis of Use of Working Capital in Increasing Profit in the Industry Sejahtera Mandiri in Malangke Barat, District North Luwu shows that the use of working capital can increase profits every year in the Mandiri Prosperous Industry [5].

Research by Pais \& Gama under the title Working capital management and SMEs profitability: Portuguese evidence, Results More aggressive practices of working capital management policies can increase the profitability of companies [6].

Kasiran, Mohamad \& Chin research entitled Working Capital Management Efficiency: A Study on Small Medium Enterprise in Malaysia shows that selected SME companies are not efficient in managing their working capital [7].

The study by Elbadry with the title The Determinants of Working Capital Management in Egyptian SMEs, The results show that Egyptian SMEs follow aggressive policies because businesses have low level working capital that leads to high returns and high risk levels (measured by LEVERAGE) [8].

The study by Batista Russo Tavares with the title The Working Capital Management: The Determinants and the Effect on Profitability: Evidence From Portuguese Smes, the results of the study found no relationship between working capital management and SME profitability [9].

\section{METHODOLOGY}

The method used is descriptive qualitative method. done by data verification process, data classification, preparation of income statement, balance sheet, calculation of the effectiveness of working capital through calculation of Current Ratio, Quick Ratio, Cash Ratio, Working Capital Turnover, Receivable Turnover, Inventory Turnover. Data sources were obtained from the financial transaction records for two semesters of 2018 MSME Rozatajaya Souvenir.

The analysis techniques used in this study are:

1. Identify the balance sheet and income statement.

2. Calculating the Current Assets of Rozatajaya Souvenir

3. Calculating the Current Debt of Rozatajaya Souvenir

4. Calculating Working Capital, using the formula:

$$
\text { Modal Kerja }=\text { Current Assets }- \text { Current Liabilities }
$$

5. Calculate the Liquidity Ratio, Liquidity ratio to describe the company's ability to complete its shortterm obligations [10]. These ratios can be calculated through sources of information about working capital, namely current asset accounts and current debt. The level of company liquidity can be known by the formula:

$$
\begin{gathered}
\text { Current Ratio }=\frac{\text { Current Assets }}{\text { Current Liabilities }} \times 100 \% \\
\text { Quick Ratio }=\frac{\text { Current Assets }- \text { Inventory }}{\text { Current Liabilities }} \times 100 \% \\
\text { Cash Ratio }=\frac{(\text { Cash }+ \text { Cash equivalent })}{\text { Current Liabilities }} \times 100 \%
\end{gathered}
$$

6. Calculate the Activity Ratio. This activity ratio is to measure the effectiveness of a company in using its assets [11]. It can also be said that this ratio is used to measure activity ability or effectiveness in utilizing company resources. The formula for measuring activity ratios is: 


$$
\begin{gathered}
\text { Working Capital Turnover }=\frac{\text { Net Sales }}{\text { Current Assets }- \text { Current Liabilities }} \\
\text { Inventory Turnover }=\frac{\text { Cost of Goods Sold }}{\text { Inventory }} \\
\text { Receiveble Turnover }=\frac{\text { Credit Sales }}{\text { Average Accounts Receivable }} \\
\text { Days of Receiveble }=\frac{\text { number of days }}{\text { Receiveble Turnover }}
\end{gathered}
$$

\section{RESULTS AND DISCUSSION}

\section{Income Statement}

To find out the effective working capital on Rozatajaya Souvenir is done by making MSME financial

\begin{tabular}{|c|c|c|c|c|}
\hline \multicolumn{5}{|c|}{$\begin{array}{l}\text { ROZATAJAYA SOUVENIR } \\
\text { INCOME STATEMENT } \\
\text { For } 1 \text { January - 30 June } 2018 \\
\end{array}$} \\
\hline Sales & & & $\mathrm{Rp}$ & 35.200 .000 \\
\hline Cost of Goods Sold & & & $\mathrm{Rp}$ & $(13.200 .000)$ \\
\hline Gross income & & & $\mathrm{Rp}$ & 22.000 .000 \\
\hline \multicolumn{5}{|l|}{ costs } \\
\hline Salary Expense & $\mathrm{Rp}$ & 3.000 .000 & & \\
\hline Transportation Costs & $\mathrm{Rp}$ & 400.000 & & \\
\hline Electricity, water, tlp Costs & $\mathrm{Rp}$ & 250.000 & & \\
\hline Miscellaneous expense & $\mathrm{Rp}$ & 200.000 & & \\
\hline Cost of depreciation & $\mathrm{Rp}$ & 3.362 .500 & & \\
\hline Total Cost & & & $\mathrm{Rp}$ & $(7.212 .500)$ \\
\hline Profit before tax & & & $\mathrm{Rp}$ & 14.787 .500 \\
\hline MSME tax $1 \%$ & & & $\mathrm{Rp}$ & 147.875 \\
\hline Pre-tax net income & & & $\mathrm{Rp}$ & 14.639 .625 \\
\hline
\end{tabular}
statements which consist of income statement and balance sheet.

The following is Rozatajaya Souvenir's income statement for the month ended June 30, 2018.

Table 3. 1 Income statement 1 January - 30 June 2018

Source : financial activity MSME Rozatajaya Souvenir

Based on table 3.1, it can be seen sales of Rp. 35,200,000 minus cost of goods sold in the amount of Rp. 13,200,000 so that the total gross income from January to June is Rp. 22,000,000. and for costs of Rp. 7,212,500. After that gross income is reduced costs so that the total profit before tax is Rp. 14,787,500. and MSME tax according to Final Income Tax Article 4 paragraph 2, which is equal to $1 \%$. Funds from the calculation of net income after tax are Rp. 14,639,625. 
The following is Rozatajaya Souvenir income statement for the month ended 31 December 2018.

Table 3. 2 Income Statement for 31 July-31 December 2018

\begin{tabular}{|c|c|c|c|c|}
\hline \multicolumn{5}{|c|}{$\begin{array}{c}\text { ROZATAJAYA SOUVENIR } \\
\text { INCOME STATEMENT } \\
\text { For } 31 \text { July - } 31 \text { December } 2018\end{array}$} \\
\hline Sales & & & $\mathrm{Rp}$ & 50.560 .000 \\
\hline Cost of Goods sold & & & $\mathrm{Rp}$ & $(18.960 .000)$ \\
\hline Gross income & & & $\mathrm{Rp}$ & 31.600 .000 \\
\hline \multicolumn{5}{|l|}{ COST } \\
\hline Salary Expense & $\mathrm{Rp}$ & 3.000 .000 & & \\
\hline Transportation Cost & $\mathrm{Rp}$ & 900.000 & & \\
\hline Electricity, water, tlp Costs & $\mathrm{Rp}$ & 500.000 & & \\
\hline Miscellaneous expense & $\mathrm{Rp}$ & 200.000 & & \\
\hline Cost of depreciation & $\mathrm{Rp}$ & 3.362 .500 & & \\
\hline Total Cost & & & $\mathrm{Rp}$ & $(7.962 .500)$ \\
\hline Profit before tax & & & $\mathrm{Rp}$ & 23.637 .500 \\
\hline MSME tax $0,5 \%$ & & & $\mathrm{Rp}$ & 118.188 \\
\hline Pre-tax net income & & & $\mathrm{Rp}$ & 23.519 .313 \\
\hline
\end{tabular}

Source : financial activity MSME Rozatajaya Souvenir

Based on table 3.2 can be seen sales of Rp. 50,560,000 minus the cost of sales of Rp. 18,960,000 so that the total gross income from July to December is Rp. 31,600,000. and for costs of Rp. 7,962,500. After that gross income is reduced costs so that the total profit before tax is Rp. 23,637,500. And MSME tax in accordance with PPh Final Article 4 paragraph 2 which is $0.5 \%$. Funds from the calculation of net income after tax are Rp. 23,519,313.

\section{Balance Sheet}

The following is the Rozatajaya Balance Sheet Souvenir report for 1 January 2018 - 30 June 2018 and 1 July 2018 - December 312018.

Table 3. 3 Balance Sheet

\section{ROZATAJAYA SOUVENIR}

BALANCE SHEET

For 1 January - 30 June 2018 and 1 July - 31 December 2018

\begin{tabular}{|c|c|c|c|c|}
\hline & \multicolumn{2}{|c|}{$\begin{array}{c}\text { 1 January - } 30 \text { June } \\
2018\end{array}$} & \multicolumn{2}{|c|}{$\begin{array}{c}1 \text { July - } 31 \\
\text { December } 2018\end{array}$} \\
\hline \multicolumn{5}{|l|}{ Current Assets : } \\
\hline Cash & $\mathrm{Rp}$ & 23.800 .000 & $\mathrm{Rp}$ & 33.950 .000 \\
\hline Bank & $\mathrm{Rp}$ & 4.800 .000 & $\mathrm{Rp}$ & 17.760 .000 \\
\hline Receivable & $\mathrm{Rp}$ & 8.000 .000 & $\mathrm{Rp}$ & 15.520 .000 \\
\hline Merchandise Inventory & $\mathrm{Rp}$ & 1.800 .000 & $\mathrm{Rp}$ & 840.000 \\
\hline Supplies & $\mathrm{Rp}$ & 600.000 & $\mathrm{Rp}$ & 540.000 \\
\hline Total current assets & $\mathrm{Rp}$ & 39.000 .000 & $\mathrm{Rp}$ & 68.610 .000 \\
\hline Fixed assets : & & & & \\
\hline
\end{tabular}




\begin{tabular}{lcrrr}
\hline Land & $\mathrm{Rp}$ & 45.000 .000 & $\mathrm{Rp}$ & 45.000 .000 \\
Buildings & $\mathrm{Rp}$ & 35.000 .000 & $\mathrm{Rp}$ & 35.000 .000 \\
Vehicles & $\mathrm{Rp}$ & 26.000 .000 & $\mathrm{Rp}$ & 26.000 .000 \\
Equipment & $\mathrm{Rp}$ & 1.000 .000 & $\mathrm{Rp}$ & 1.000 .000 \\
Buildings accumulated depr. & $\mathrm{Rp}$ & $(1.250 .000)$ & $\mathrm{Rp}$ & $(1.250 .000)$ \\
Vehicles accumulated depr. & $\mathrm{Rp}$ & $(2.000 .000)$ & $\mathrm{Rp}$ & $(2.000 .000)$ \\
Equipment accumulated depr. & $\mathrm{Rp}$ & $(112.500)$ & $\mathrm{Rp}$ & $(112.500)$ \\
Total fixed assets & $\mathrm{Rp}$ & 23.750 .000 & $\mathrm{Rp}$ & 23.750 .000 \\
Total Assets & $\mathrm{Rp}$ & 62.750 .000 & $\mathrm{Rp}$ & 92.910 .000 \\
LIABILITIES AND EQUITY & & & & \\
Current Liability : & & & & \\
Accounts payable & $\mathrm{Rp}$ & 15.000 .000 & $\mathrm{Rp}$ & 20.000 .000 \\
Total Current liability & $\mathrm{Rp}$ & 15.000 .000 & $\mathrm{Rp}$ & 20.000 .000 \\
Equity : & & & & \\
Capital & $\mathrm{Rp}$ & 47.750 .000 & $\mathrm{Rp}$ & 72.360 .000 \\
Total liability and Equity & $\mathrm{Rp}$ & 62.750 .000 & $\mathrm{Rp}$ & 92.360 .000 \\
\hline \multicolumn{2}{c}{ Source f financial activity MSME Rozatajaya Souvenir } & &
\end{tabular}

Based on Table 3.3 above, it can be seen that the balance sheet reports from 1 January to 30 June 2018 total current assets of Rp. 39,000,000 consisting of cash, banks, accounts receivable, inventory of merchandise and equipment. It can also be seen that current liabilities are Rp. 15,000,000. While the balance sheet reports for July 1 to December 312018 total current assets of Rp. 68,610,000 consisting of cash, banks, accounts receivable, inventory of merchandise and equipment. It can also be seen that current liabilities are Rp. 20,000,000.

Working Capital Composition

Table 3. 4 Working Capital Composition

\begin{tabular}{|c|c|c|}
\hline & $\begin{array}{c}\text { 1 January - } 30 \text { June } \\
2018\end{array}$ & $\begin{array}{c}\text { 1 July - } 31 \text { December } \\
2018\end{array}$ \\
\hline Current assets & $\begin{array}{ll}\mathrm{Rp} & 39.000 .000\end{array}$ & $\begin{array}{ll}\mathrm{Rp} & 68.610 .000\end{array}$ \\
\hline Current liabilities & 15.000 .000 & $\operatorname{Rp} \quad 20.000 .000$ \\
\hline Net Working Capital & Rp $\quad 24.000 .000$ & Rp $\quad 48.610 .000$ \\
\hline
\end{tabular}

From the data above, the total current assets or assets that can be cashed when needed assets that can be cashed immediately when needed, at the Rozatajaya Souvenir in January - June 2018 are Rp. 39,000,000. Total current assets in July - December 2018 are Rp. 68,610,000.

Then reduced by Current liabilities that must be paid immediately in the near term or a maximum of 1 year, at the Rozatajaya Souvenir of Rp. 15,000,000. In July - December 2018 in the amount of Rp. $20,000,000$.

Total Working Capital obtained from formula number 1, in January - June 2018 at the MSME Rozatajaya Souvenir of Rp. 24,000,000. In July - December 2018 Total Working Capital Increases by Rp. 48,610,000.

\section{Liquidity Ratio}

Table 3. 5 Liquidity Ratios

\begin{tabular}{lcc}
\hline & Table 3.5 Liquidity Ratios & \\
\hline Liquidity Ratios & 1 January -30 June & 1 July -31 December \\
& 2018 & 2018 \\
\hline Current Ratio & 2,60 or $260 \%$ & 3,43 or $343 \%$ \\
Quick Ratio & 2,48 or $248 \%$ & 3,39 or $339 \%$ \\
Cash Ratio & 1,91 or $191 \%$ & 2,59 or $259 \%$ \\
\hline
\end{tabular}


Source : data processed

From the calculation above, the Current Ratio is calculated from formula number 2 , the current ratio for January-June 2018 is 2.60 or every Rp 1 current debt is guaranteed by Rp 2.60 current assets. While the current ratio for July-December 2018 increased by 3.43 or every IDR 1 current debt guaranteed by IDR 3.43 current assets. The ratio standard according to Harahap is smooth 1: 1 or $100 \%$, meaning that every current debt of $\mathrm{Rp} 1$ is guaranteed by current assets of $\mathrm{Rp}$ 1 , it is considered good enough for the company, meaning that the current assets must be above current debt [10]. So that the current ratio for January-June 2018 and July-December 2018 is considered good because it is above the current ratio standard.

Quick ratio calculated from formula number 3, for January-June 2018 every IDR 1 current debt is guaranteed by current assets other than inventories of $\mathrm{Rp} 2.48$. While the number of quick ratios for July-December 2018 means that every IDR 1 current debt is guaranteed by current assets other than inventories of $\mathrm{Rp}$ 3.39. Standard according to Harahap quick ratio does not have to be $100 \%$ or 1: 1 Even though the ratio does not reach $100 \%$ but close to $100 \%$ has also been said to be good [10]. So that the quick ratio of January-June 2018 and July-December 2018 is considered good because it is above the current ratio standard. for a higher current ratio for July-December 2018.

Cash Ratio which is calculated from formula number 4, for January-June 2018 every Rp 1 current debt is guaranteed by cash and cash equivalents of Rp 1.91. While the ability of cash for JulyDecember 2018 increased by Rp 2.59, which means that every IDR 1 current debt is guaranteed by cash and cash equivalents of Rp 2.59. From this comparison the cash ratio in July-December 2018 is higher, the higher the ratio the better.

\section{Activity ratio}

Table 3. 6 Activity Ratios

\begin{tabular}{lcc}
\hline Activity Ratios & 1 January -30 & 1 July -31 December \\
& June 2018 & 2018 \\
\hline Working Capital Turnover & 1,47 & 1,04 \\
Inventory Turnover & 7,33 & 22,57 \\
Receivable Turnover & 5,33 & 3,10 \\
Days of Receivable & 34 Days & 60 Days \\
\hline
\end{tabular}

Source : data processed

Based on the calculation above, working capital turnover is calculated from formula number 5, for January-June 2018 each Rp. 1 working capital can generate Rp. 1.47 in sales. Whereas the working capital turnover for July-December 2018 fell by 1.04 or every Rp. 1 working capital could generate as much as 1.04 rupiah in sales. This shows the lack of management of existing working capital management. While the standard according to Kasmir is 6 times [11], it can be said that the working capital turnover ratio is not effective because it is below the standard.

Inventory turnover, calculated from formula number 6, for January-June 2018 is 7.33 times, this indicates that the funds stored in inventory spinning are 7.33 times in six months. While inventory turnover for July-December 2018 increased by 22.57 times, this indicates that the funds stored in inventory spinning as much as 22.57 times in six months. Whereas According to Kasmir the standard ratio of effective inventory is 20 times [11]. It can be said that inventory turnover in January-June 2018 is ineffective because it is below the standard, while inventory turnover in JulyDecember 2018 is effective because it is above the standard. the lower the existing inventory turnover, the higher working capital needed. on the contrary, the higher the inventory turnover is, the lower the working capital needed.

Account receivable turnover, calculated from formula number 7, for January-June 2018 is 5.33 times in six months, from credit sales, to the average collection of receivables for 34 days. While the accounts receivable turnover for July-December 2018 decreased by 3.10 times, in six months, from credit sales, for the average collection of accounts receivable for 60 days. Whereas According to Kasmir effective rotation standard is 15 times [11]. Low accounts receivable turnover means working capital is tied to longer. It can be said that the accounts receivable turnover in January-June 2018 and July-December 2018 is less effective because it is below the standard. Whereas, for the average 
collection of accounts receivable, the credit terms provided are 60 days, then the average day of receivables collection is said to be quite good.

\section{CONCLUSION}

Based on the results of research and discussion, conclusions can be drawn as follows:

1. The Liquidity Ratio is very good, with the value covering the Current Ratio in the first half of 2018 per Rp 1 current debt guaranteed by Rp 2.60 current assets for the second semester rose by Rp 3.43 current assets. Quick Ratio for the first semester of 2018 for every IDR 1 current debt guaranteed by current assets in addition to inventories of $\mathrm{Rp} 2.48$ for the second semester of the month which increased by Rp 3.39. Cash Ratio for the first semester of 2018 for every Rp 1 current debt guaranteed by cash and cash equivalents of Rp 1.91 for the second semester rose by $\mathrm{Rp} 2.59$.

2. The Effectiveness of Working Capital using the Activity Ratio is considered to be less effective, with the value covering Working Capital Turnover for the first semester of 2018 each IDR 1 working capital can generate Rp 1.47 sales for the second half decreasing by Rp 1.04 sales. This shows the lack of management of existing working capital management. Inventory Turnover for the first semester of 2018 shows that funds stored in spinning inventory amounted to 7.33 times in six months and for the second semester month increased by 22.57 times in six months. Receivable Turnover shows receivable turnover for the first half of 2018 amounting to 5.33 times in six months from credit sales, the average collection of receivables for 34 days and for the second semester decreased by 3.10 times in six months from credit sales, for the average collection of accounts for 60 days. Whereas, for the average collection of accounts receivable, the credit terms provided are 60 days, then the average day of receivables collection is said to be quite good.

\section{SUGGESTIONS}

Based on the results of the discussion of conclusions, the researchers suggested that Rozatajaya Souvenir MSMEs should be more effective in utilizing their sources of funds or assets, so that the company would be more careful in using working capital to increase sales.

\section{REFERENCES}

[1] J. F. Weston and E. F. Brigham, Dasar-dasar Manajemen keuangan, Ketujuh. Penerbit Erlangga, 1994.

[2] Bambang Rianto, Dasar-Dasar Pembelajaran Perusahaan, Edisi 4. Yogyakarta: BPFE, 2011.

[3] A. R. F. Sukoco, M. W. E. N.P, and Z. ZA, "Pengelolaan Modal Kerja Usaha Mikro Untuk Memperoleh Profitabilitas (Studi pada UD. Warna Jaya Periode 2011-2013)," J. Adm. Bisnis, vol. $22,2015$.

[4] D. Wahyuni, "Analisis Efisiensi Penggunaan Modal Kerja Pada UD. Arifa Souvenir Jombang," vol. 10, no. 2, 2016.

[5] Goso and Indriani, “Analisis Penggunaan Modal Kerja Dalam Meningkatkan Laba Pada Industri Sejahtera Mandiri Di Kecamatan Malangke Barat Kabupaten Luwu Utara,” vol. 01, no. 02, pp. 18, 2014.

[6] M. A. Pais and P. M. Gama, "Working capital management and SMEs profitability: Portuguese evidence," Int. J. Manag. Financ., 2015.

[7] F. W. Kasiran, N. A. Mohamad, and O. Chin, "Working Capital Management Efficiency: A Study on the Small Medium Enterprise in Malaysia," Procedia Econ. Financ., 2016.

[8] A. Elbadry, "The Determinants of Working Capital Management in the Egyptian SMEs," Account. Financ. Res., 2018.

[9] J. F. Tavares Batista Russo, "The working capital management: the determinants and the effect on profitability: Evidence from Portuguese SMEs,” no. October, p. 85, 2013.

[10] S. S. Harahap, Analisis Kritis atas Laporan Keuangan, Ed 1. Jakarta: Rajawali Pers, 2015.

[11] Kasmir, Analisis Laporan Keuangan, Ed. 1. Jakarta: Rajawali Pers, 2016. 